\title{
Effect of 6-benzyl-aminopurine and thidiazuron on in vitro shoot organogenesis of Aloe vera (L.) Burm.f.
}

\author{
Lavanya Lavakumaran ${ }^{1}$, and Thayamini H. Seran ${ }^{1 *}$
}

\begin{abstract}
Aloe (Aloe vera [L.] Burm. f.) is an important medicinal herb and is propagated vegetatively. However, its propagation rate is slow and cannot supply good quality planting material to large-scale growers. It is therefore necessary to use in vitro clonal propagation for commercial purposes. The aim of this study was to select a suitable medium for initial culture establishment and subsequent shoot multiplication of aloe. Shoot tips were excised from aloe plants and disinfected with $20 \%$ Clorox (5.25\% sodium hypochlorite) for $30 \mathrm{~min}$. Sterilized shoot tips were vertically dissected into quarters and then inoculated on Murashige and Skoog (MS) medium supplemented with 6-benzylaminopurine (BAP) or thidiazuron (TDZ) $\left(1,2\right.$, and $\left.3 \mathrm{mg} \mathrm{L}^{-1}\right)$ combined with $0.5 \mathrm{mg} \mathrm{L}^{-1} 1$-naphthaleneacetic acid (NAA). Results revealed that there was a significant difference $(\mathrm{P}<0.05)$ between different hormone combinations in shoot bud formation. Explants placed in $3 \mathrm{mg} \mathrm{L} \mathrm{L}^{-1} \mathrm{BAP}$ and $0.5 \mathrm{mg} \mathrm{L}^{-1}$ NAA produced significantly $(\mathrm{P}<0.05)$ higher numbers of microshoots than other tested treatments. The medium containing a low concentration of TDZ $\left(1 \mathrm{mg} \mathrm{L}^{-1}\right)$ with NAA produced multiple microshoots, whereas the highest TDZ concentration $\left(3 \mathrm{mg} \mathrm{L}^{-1}\right)$ with NAA produced high levels of abnormalities. Transferring microshoot buds from $1 \mathrm{mg}$ $\mathrm{L}^{-1} \mathrm{TDZ}$ to $3 \mathrm{mg} \mathrm{L}^{-1} \mathrm{BAP}$ accelerated production of prominent and elongated shoots. The MS medium supplemented with $3 \mathrm{mg} \mathrm{L}^{-1} \mathrm{BAP}$ and $0.5 \mathrm{mg} \mathrm{L}^{-1}$ NAA produced higher number of normal shoots per explant of aloe under in vitro conditions.
\end{abstract}

Key words: Aloe, BAP, microshoots, in vitro culture, organogenesis, TDZ.

\section{INTRODUCTION}

Aloe vera (L.) Burm. $\mathrm{f}$ is an important medicinal plant belonging to the Liliaceae family; it is also called the burn plant, first aid plant, and miracle plant (Tanabe and Horiuchi, 2006). It is a monocotyledon plant that grows naturally in most of the tropics and is commercially cultivated in many countries. Aloe vera is being used in the pharmaceutical and cosmetic industries (Campestrini et al., 2006; Tanabe and Horiuchi, 2006) and is very popular for commercial and therapeutic uses (Park and Lee, 2006). The most important by-products of aloe are latex and gel that are taken from the parenchyma cells of the leaves (Ni et al., 2004). Seed propagation is not effective in A. vera and is mostly propagated by axillary shoots. However, large-scale propagation for commercial cultivation is difficult due to the low number of axillary shoots produced by a single plant. Conventional vegetative propagation of aloe cannot adequately supply the increasing demand for planting materials (Hosseini and Parsa, 2007). In vitro propagation is therefore an alternative to increase commercial production of aloe (Campestrini et al., 2006; Silva et al., 2007).

${ }^{1}$ Eastern University, Chenkalady, Sri Lanka.

*Corresponding author (thayaseran@yahoo.com).

Received: 28 January 2014.

Accepted: 8 September 2014.

doi:10.4067/S0718-58392014000400018
In vitro shoot proliferation mainly depends on plant growth regulators, particularly cytokinins and auxin incorporated in the culture medium. Liao et al. (2004) and Debiasi et al. (2007) stated the impact of benzyladenine (BA), indole-3-acetic acid (IAA), and 1-naphthaleneacetic acid (NAA) on bud initiation. According to available literature, thidiazuron (TDZ) is a diphenylurea derivative and is not widely used in micropropagation of aloe species although it has had a significant effect on shoot proliferation of other plant species. Faisal et al. (2005) reported that TDZ is a substitute for phenylurea to stimulate axillary shoot proliferation in several plant species. Therefore, this study was conducted to investigate the effect of BAP and TDZ on shoot formation of aloe under in vitro conditions.

\section{MATERIALS AND METHODS}

This experiment was carried out in 2013 at the Tissue Culture Laboratory, Eastern University of Sri Lanka, Chenkalady, Sri Lanka $\left(7^{\circ} 43^{\prime} \mathrm{N}, 81^{\circ} 42^{\prime} \mathrm{E}\right)$. Aloe mother plants $(2$ mo old) were collected from a net house in the Eastern Region of Sri Lanka and subsequently washed thoroughly under running tap water for approximately $40 \mathrm{~min}$. Shoot tips were excised from the collected mother plants and dipped in $70 \%$ ethanol for $30 \mathrm{~s}$. They were then disinfected with $20 \%$ Clorox $(5.25 \%$ sodium hypochlorite) and two drops of Tween 20 for $30 \mathrm{~min}$ and washed three times with sterile distilled water. 
Sterilized shoot tips $(1.5 \times 0.5 \mathrm{~cm})$ were vertically dissected into equal quarters. Explants were inoculated on Murashige and Skoog (MS) medium supplemented with various concentrations $\left(1,2\right.$, and $\left.3 \mathrm{mg} \mathrm{L}^{-1}\right)$ of 6-benzylaminopurine (BAP) or thidiazuron (TDZ, 1-phenyl-3-[1,2,3-thiadiazol-5-yl] urea) combined with $0.5 \mathrm{mg} \mathrm{L}^{-1}$ 1-naphthaleneacetic acid (NAA). Culture vessels containing explants were then incubated at $25 \pm$ $2{ }^{\circ} \mathrm{C}$ under fluorescent light with 18:06 h photoperiod. Light intensity of 2000 lux and $70 \%$ humidity were maintained. Cultures were constantly observed for any in vitro response. This experiment was conducted with a complete randomized design and three replicates repeated three times. The percentage of explants showing shoot bud formation, number of newly emerged shoots per explant, number of leaves per shoot, and shoot length were recorded at 2-wk intervals.

After a 4-wk culture, microshoots from the selected initial culture media were transferred to fresh MS medium containing $3 \mathrm{mg} \mathrm{L}^{-1} \mathrm{BAP}$ and $0.5 \mathrm{mg} \mathrm{L}^{-1} \mathrm{NAA}$ for shoot multiplication and further investigation. The elongated microshoots were transferred to hormone-free MS medium for in vitro plantlet regeneration. Microplantlets were then removed from the culture bottles and washed to remove agar. Plantlets were transferred to sterile poly pots containing top soil, sand, and cow dung at 1:1:1 ratio. Plastic pots were covered with a transparent polythene bag to maintain high relative humidity around the plants. Data were subjected to ANOVA with SAS software (SAS Institute, Cary, North Carolina, USA). Percentage data were analyzed and the significant difference between treatment means was estimated by Tukey's honestly significant difference (HSD) test at 5\% significance level.

\section{RESULTS AND DISCUSSION}

\section{Culture establishment}

In vitro response in all treatment combinations was noted within $1 \mathrm{wk}$ after culturing the explants. During this period, the color of explants changed to dark green and slight swelling was observed. All treatments produced morphogenic response. Both BAP and TDZ showed the sign of shoot proliferation after a 2-wk culture. Thidiazuron and BA exhibited efficient shoot induction in A. arborescens (Velcheva et al., 2005). Initially, shoot buds were light green in color and emerged either singly or in clusters. Callus formation did not occur at the cut end of the explants. Data reveal a significant variation $(\mathrm{P}<0.05)$ in the effect of different hormone combinations on the percentage of explants showing bud formation (Table 1).

The MS medium supplemented with $3 \mathrm{mg} \mathrm{L}^{-1} \mathrm{BAP}$ showed low morphogenic response compared with medium with $1 \mathrm{mg} \mathrm{L}^{-1} \mathrm{TDZ}$ at the second week of culture; however, at the fourth week, explants cultured on medium containing $3 \mathrm{mg} \mathrm{L}^{-1} \mathrm{BAP}$ exceeded the response rate of those cultured in TDZ. This shows that during the early stages of culture, TDZ had higher in vitro response than BAP. The medium with $3 \mathrm{mg} \mathrm{L}^{-1} \mathrm{BAP}$ or $1 \mathrm{mg} \mathrm{L}^{-1} \mathrm{TDZ}$ in addition to $0.5 \mathrm{mg} \mathrm{L}^{-1} \mathrm{NAA}$ showed greater shoot bud initiation response than other treatments.

Thidiazuron and BAP boost cell division and break apical dominance (Tawfik and Mohamed, 2006). As a result, shoot proliferation of cultured shoot tips was noted in the presence of BAP and TDZ. The highest percentage of explants showing bud formation was obtained in medium supplemented with $3 \mathrm{mg} \mathrm{L}^{-1}$ BAP followed by $1 \mathrm{mg} \mathrm{L}^{-1}$ TDZ. Both auxin and cytokinin are crucial for shoot proliferation (Velcheva et al., 2005), and cytokinin is an important plant growth regulator in shoot formation.

There is a significant difference $(\mathrm{P}<0.05)$ between media containing $2 \mathrm{mg} \mathrm{L}^{-1}$ and $3 \mathrm{mg} \mathrm{L}^{-1} \mathrm{BAP}$ in the production of single microshoots larger than $5 \mathrm{~mm}$ (Table 1). Other treatments were not considered for the statistical analysis because they produced miniature buds and malformations. A relatively higher number of shoot buds per explant (3.3) was observed in the presence of $3 \mathrm{mg} \mathrm{L}^{-1}$ BAP and $0.5 \mathrm{mg} \mathrm{L}^{-1} \mathrm{NAA}$. Shoots are green in color and consist of five leaves per shoot (Figure 1). It was found that $3 \mathrm{mg} \mathrm{L}^{-1} \mathrm{BAP}$ produced higher shoot proliferation than $2 \mathrm{mg} \mathrm{L}^{-1}$ BAP. Generally, cytokinins induce adventitious bud formation. In the present study, high shoot bud initiation occurred in the presence of high levels of cytokinin. The highest BAP concentration in the medium induced more shoot development than the lowest

Table 1. Effect of 6-benzylaminopurine (BAP) and thidiazuron (TDZ) on shoot formation in Aloe vera after 4-wk culture.

\begin{tabular}{lccl}
\hline $\begin{array}{l}\text { Plant growth } \\
\text { regulators }\end{array}$ & $\begin{array}{c}\text { Explants showing bud } \\
\text { formation }\end{array}$ & $\begin{array}{c}\text { Number of microshoots } \\
(>5 \mathrm{~mm})\end{array}$ & \multicolumn{1}{c}{ Remarks } \\
\hline mg L-1 & $\%$ & $0.00^{1}$ & Normal shoot growth $(<5 \mathrm{~mm})$ \\
$1 \mathrm{BAP}+0.5 \mathrm{NAA}$ & $25.00 \mathrm{~d}$ & $1.7 \pm 0.3$ & Normal shoot growth \\
$2 \mathrm{BAP}+0.5 \mathrm{NAA}$ & $48.70 \mathrm{c}$ & $3.3 \pm 0.3$ & Normal shoot growth \\
$3 \mathrm{BAP}+0.5 \mathrm{NAA}$ & $67.30 \mathrm{a}$ & - & Multiple shoot bud formation $(<5 \mathrm{~mm})$ \\
$1 \mathrm{TDZ}+0.5 \mathrm{NAA}$ & $63.00 \mathrm{ab}$ & - & Stunted shoot growth \\
$2 \mathrm{TDZ}+0.5 \mathrm{NAA}$ & $58.00 \mathrm{bc}$ & - & Malformation \\
$3 \mathrm{TDZ}+0.5 \mathrm{NAA}$ & $54.70 \mathrm{bc}$ & - & \\
\hline F-test & $\mathrm{P}<0.05$ & $\mathrm{P}<0.05$ & \\
t-test & - & &
\end{tabular}

${ }^{1}$ Not considered for the statistical analysis due to zero value. Data represent mean of 48 explants. Values followed by the same letter are not significantly different according to Tukey's test $(\mathrm{P}<0.05)$.

NAA: 1-Naphthaleneacetic acid. 

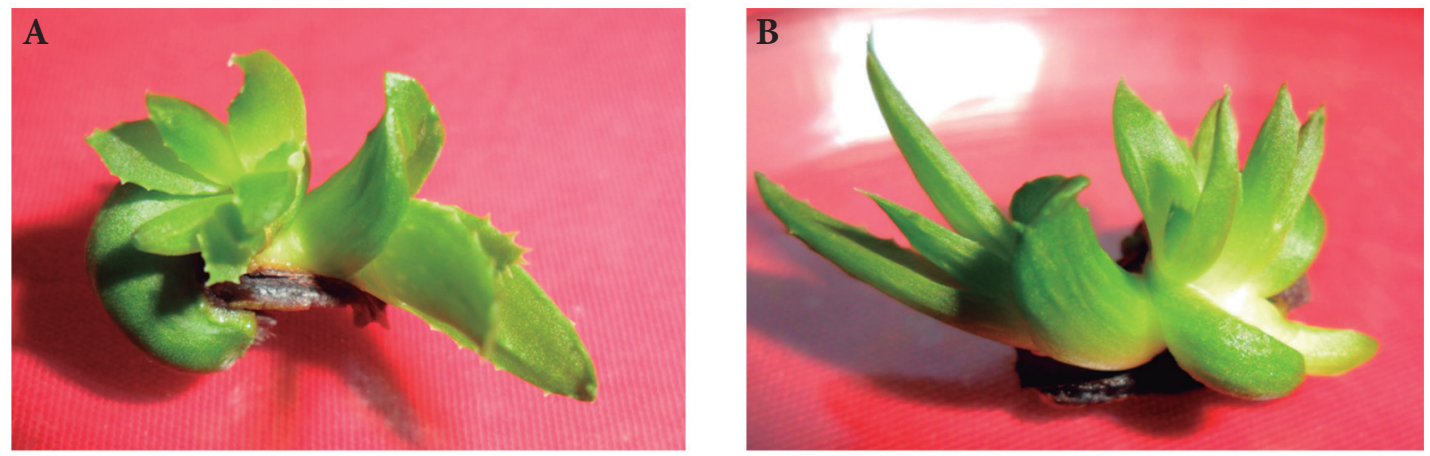

Figure 1. Microshoot formation of Aloe vera explants cultured on MS medium containing $2 \mathrm{mg} \mathrm{L}^{-1}$ (A) and 3 mg $\mathrm{L}^{-1}$ (B) 6-benzylaminopurine in combination with $0.5 \mathrm{mg} \mathrm{L}^{-1} 1$-naphthaleneacetic acid after 5-wk culture (3X).

BAP concentration among the concentrations $(0.5$ to 5 $\mathrm{mg} \mathrm{L}^{-1}$ ) tested by Zuraida et al. (2011). Explants cultured on MS medium with $1 \mathrm{mg} \mathrm{L}^{-1} \mathrm{BAP}$ and $0.5 \mathrm{mg} \mathrm{L}^{-1} \mathrm{NAA}$ failed to produce shoot buds larger than $5 \mathrm{~mm}$ after a 4-wk culture. It produced only one miniature bud that did not develop further into shoots and was inhibited; the lowest percentage of shoot induction was also obtained in the same media. In contrast, Aggarwal and Barna (2004) report the highest shoot multiplication recorded in A. vera on MS medium containing $1 \mathrm{mg} \mathrm{L}^{-1} \mathrm{BA}$ and $0.2 \mathrm{mg} \mathrm{L}^{-1}$ indole-3-butyric acid (IBA).

The percentage of explants showing shoot formation and number of shoots per explant increased with increasing BAP concentration (1 to $3 \mathrm{mg} \mathrm{L}^{-1}$ ). This result is in line with the findings in pineapple by Be and Debergh (2006), who report higher production of axillary shoots per explant when BAP concentration increases. Wenping et al. (2004) report more than $95 \%$ shoot proliferation in medium with BA and NAA. When the concentration of TDZ increased from $1 \mathrm{mg} \mathrm{L}^{-1}$ to $3 \mathrm{mg} \mathrm{L}^{-1}$, the percentage of explants showing bud formation decreased. At the same time, the number of malformed shoots increased with increasing TDZ concentration. The medium containing the lowest concentration of TDZ $\left(1 \mathrm{mg} \mathrm{L}^{-1}\right)$ combined with NAA $\left(0.5 \mathrm{mg} \mathrm{L}^{-1}\right)$ produced multiple shoots (clumps of buds); this indicates that $1 \mathrm{mg} \mathrm{L}^{-1} \mathrm{TDZ}$ is better for shoot proliferation, but shoots are difficult to excise and have a yellowish green color. They are slightly succulent and do not show any malformations (Figure 2).

In the present study, plantlets grown in the medium containing $2 \mathrm{mg} \mathrm{L}^{-1} \mathrm{TDZ}$ combined with $0.5 \mathrm{mg} \mathrm{L}^{-1} \mathrm{NAA}$ showed stunted appearance. Although shoot initiation was observed, plant growth was retarded. This can be due to the high cytokinin activity of TDZ (Figure 2). Iram and Anis (2007) state that TDZ showed a stronger effect than other normally used cytokinins. The type of growth regulators incorporated in the culture medium affects shoot production and morphology of in vitro plantlets. It was noted that the highest TDZ concentration ( $3 \mathrm{mg} \mathrm{L}^{-1}$ ) combined with NAA produced high levels of abnormalities. This might be due to the presence of a high TDZ concentration. A high cytokinin level in the medium causes cytogenetic instability (Qu et al., 2000) and is thus unsuitable for clonal propagation. An optimal level of cytokinin is required to induce adventitious shoot buds.

\section{Shoot multiplication}

Explants cultured on MS medium containing $3 \mathrm{mg} \mathrm{L}^{-1}$ BAP or $1 \mathrm{mg} \mathrm{L}^{-1}$ TDZ combined with $0.5 \mathrm{mg} \mathrm{L}^{-1} \mathrm{NAA}$ (first medium) were selected for shoot proliferation after a 4-wk culture because they showed higher in vitro response than other treatments. In the present study, BAP and NAA were selected for shoot multiplication. According to the literature, BA is better than other cytokinins for shoot
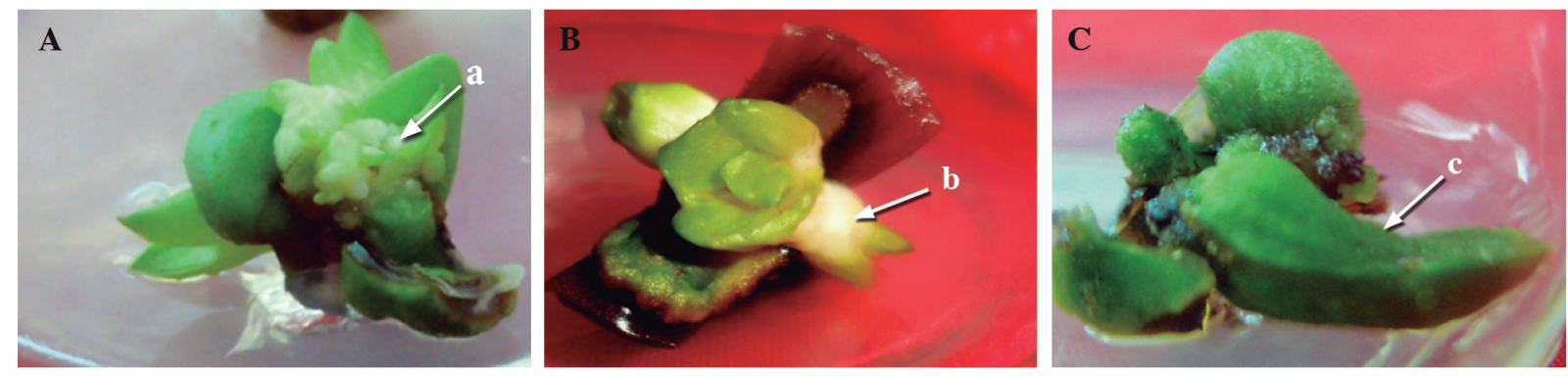

a: clumps of buds; b: stunted shoots; c: malformations.

Figure 2. In vitro response of Aloe vera explants cultured on MS medium containing $1 \mathrm{mg} \mathrm{L}^{-1}(\mathrm{~A}), 2 \mathrm{mg} \mathrm{L^{-1 }}$ (B), and $3 \mathrm{mg} \mathrm{L}^{-1}$ (C) thidiazuron in combination with $0.5 \mathrm{mg} \mathrm{L}^{-1}$ 1-naphthaleneacetic acid after 4-wk culture (3X). 
proliferation. Efficient shoot initiation was noted in a medium with BA (Velcheva et al., 2005). Microshoots from the MS medium supplemented with $3 \mathrm{mg} \mathrm{L}^{-1} \mathrm{BAP}$ and $0.5 \mathrm{mg} \mathrm{L}^{-1}$ NAA were subcultured on the same medium (second medium) (Table 2). On the other hand, multiple shoots from $1 \mathrm{mg} \mathrm{L}^{-1} \mathrm{TDZ}$ were subsequently transferred to MS medium with $3 \mathrm{mg} \mathrm{L}^{-1} \mathrm{BAP}$ and 0.5 $\mathrm{mg} \mathrm{L}^{-1}$ NAA (second medium). Debnath (2005) states that TDZ inhibits shoot growth; therefore, explants should be transferred to medium with other cytokinin to form normal shoots. Linchy and Sasikumar (2010) report that explants can change from solid to liquid to reduce the TDZ effect.

There is a significant difference $(\mathrm{P}<0.05)$ in microshoot production between the above mentioned treatments. Explants placed on $3 \mathrm{mg} \mathrm{L}^{-1} \mathrm{BAP}$ as first and second medium produce a significantly $(\mathrm{P}<0.05)$ higher number of microshoots when compared with explants placed on $1 \mathrm{mg} \mathrm{L}^{-1} \mathrm{TDZ}$ in the first medium and $3 \mathrm{mg} \mathrm{L}^{-1} \mathrm{BAP}$ in the second medium (Table 2). Shoot buds proliferate on medium containing $1 \mathrm{mg} \mathrm{L}^{-1} \mathrm{TDZ}$ and $0.5 \mathrm{mg} \mathrm{L}^{-1} \mathrm{NAA}$ and produce a higher number of buds when subcultured on the second medium (Figure 1). When explants in 1 $\mathrm{mg} \mathrm{L}^{-1} \mathrm{TDZ}$ were transferred to $3 \mathrm{mg} \mathrm{L}^{-1}$ BAP with 0.5 mg L ${ }^{-1}$ NAA, clumps became more prominent. Multiple shoot production from explants had a mean of 4.7 shoots per explant and 2 shoots were more than $1 \mathrm{~cm}$ in length. Shoots were light green in color, slightly succulent, and had five leaves (Figure 3).

When subcultured, shoot buds proliferated on MS medium containing both $3 \mathrm{mg} \mathrm{L}^{-1} \mathrm{BAP}$ and $0.5 \mathrm{mg} \mathrm{L}^{-1}$ NAA. Multiple shoot production from explants had a mean of 6.3 shoots per explant and 4.7 shoots were longer than $1 \mathrm{~cm}$ (Table 2). It exhibited good growth shoots which were dark green in color and had five leaves per shoot. The maximum number of shoots per explant was also found in the medium fortified with $3 \mathrm{mg} \mathrm{L}^{-1} \mathrm{BAP}$ and $0.5 \mathrm{mg} \mathrm{L}^{-1} \mathrm{NAA}$ in the first and second medium. It was noted that the number of shoots produced by the 8 -wk culture was double the number of shoots produced by the 4-wk culture. Liao et al. (2004) also report that a combination of BAP and NAA enhanced multiple shoot proliferation from shoot tip explants of A. barbadensis. The MS medium containing BAP and NAA is the best medium for aloe micropropagation (Wenping et al., 2004). This also agrees with our present findings.

\section{In vitro plantlets}

Shoots from explants placed on $3 \mathrm{mg} \mathrm{L}^{-1} \mathrm{BAP}$ in the first and second medium were excised individually from the proliferated shoot clumps and cultured on hormone-free medium to induce rooting. Meanwhile, microshoots were not selected for rooting from explants placed on $1 \mathrm{mg}$ $\mathrm{L}^{-1} \mathrm{TDZ}$ in the first medium and $3 \mathrm{mg} \mathrm{L}^{-1} \mathrm{BAP}$ in the second medium because they produced succulent shoots. Aggarwal and Barna (2004) demonstrate that rooting of aloe microshoots was better in medium without hormones than in medium containing IBA.

\section{CONCLUSIONS}

In the present study, medium supplemented with 6-benzylaminopurine (BAP) and 1-naphthaleneacetic

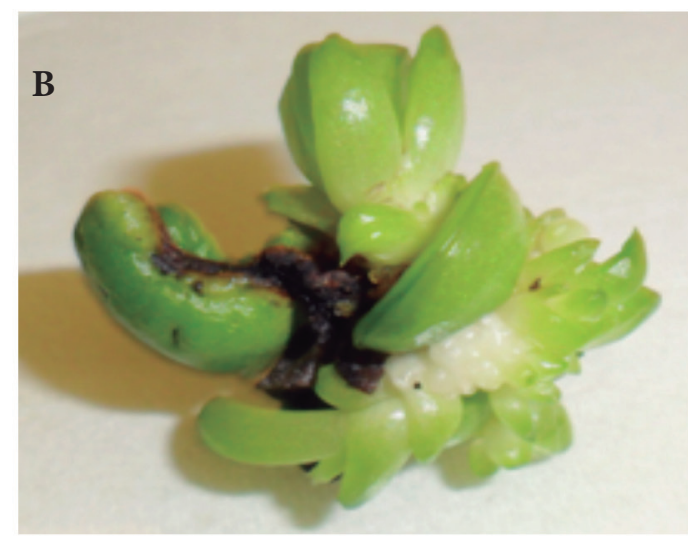

Figure 3. Aloe vera shoot proliferation after 8-wk culture in $1 \mathrm{mg} \mathrm{L}^{-1}$ thidiazuron and $0.5 \mathrm{mg} \mathrm{L}^{-1} 1$-naphthaleneacetic acid (NAA) for 4 wk and then cultured in $3 \mathrm{mg} \mathrm{L}^{-1}(\mathrm{~A}, \mathrm{~B}) 6$-benzylaminopurine and $0.5 \mathrm{mg} \mathrm{L}^{-1} \mathrm{NAA}$ for another $4 \mathrm{wk}(3 \mathrm{X})$.

Table 2. Shoot multiplication in Aloe vera after 8-wk culture on media with plant growth regulators.

\begin{tabular}{|c|c|c|c|}
\hline First medium (4 wk) & Second medium (4 wk) & Number of microshoots & $\mathrm{Nr}$ of shoots $>1 \mathrm{~cm}$ length \\
\hline $3 \mathrm{mg} \mathrm{L}^{-1} \mathrm{BAP}+0.5 \mathrm{mg} \mathrm{L}^{-1} \mathrm{NAA}$ & $3 \mathrm{mg} \mathrm{L}^{-1} \mathrm{BAP}+0.5 \mathrm{mg} \mathrm{L}^{-1} \mathrm{NAA}$ & $6.3 \pm 0.3$ & 4 \\
\hline $1 \mathrm{mg} \mathrm{L}^{-1} \mathrm{TDZ}+0.5 \mathrm{mg} \mathrm{L}^{-1} \mathrm{NAA}$ & $3 \mathrm{mg} \mathrm{L}^{-1} \mathrm{BAP}+0.5 \mathrm{mg} \mathrm{L}^{-1} \mathrm{NAA}$ & $4.7 \pm 0.3$ & 2 \\
\hline t-test & \multicolumn{2}{|c|}{$P<0.05$} & \\
\hline
\end{tabular}

Data based on explant availability.

BAP: 6-benzylaminopurine, NAA: 1-naphthaleneacetic acid, TDZ: thidiazuron 
acid (NAA) showed better morphogenic response for aloe in vitro propagation. The highest percentage of explants showing bud formation was obtained in media containing $3 \mathrm{mg} \mathrm{L}^{-1}$ BAP combined with NAA followed by $1 \mathrm{mg} \mathrm{L}^{-1}$ thidiazuron (TDZ) combined with NAA. Malformation was noted at the highest TDZ concentration $\left(3 \mathrm{mg} \mathrm{L}^{-1}\right)$. The transfer of microshoot buds from $1 \mathrm{mg} \mathrm{L}^{-1} \mathrm{TDZ}$ to 3 $\mathrm{mg} \mathrm{L}^{-1} \mathrm{BAP}$ promoted the production of elongated shoots. The present study suggests that MS medium containing 3 $\mathrm{mg} \mathrm{L}^{-1}$ BAP could boost normal shoot proliferation of in vitro Aloe vera shoot tips.

\section{LITERATURE CITED}

Aggarwal, D., and K.S. Barna. 2004. Tissue culture propagation of elite plant of Aloe vera (L.) Journal of Plant Biochemistry and Biotechnology 13:77-79.

Be, L.V., and P.C. Debergh. 2006. Potential low-cost micropropagation of pineapple (Ananas comosus). South African Journal of Botany 72:191-194.

Campestrini, L.H., S. Kuhnen, P.M.M. Lemos, D.B. Bach, P.F. Dias, and M. Maraschin. 2006. Cloning protocol of Aloe vera as a studycase for "tailor-made" biotechnology to small farmers. Journal of Technology Management and Innovation 1(5):76-79.

Debiasi, C., C.G. Silva, and R. Pescador. 2007. Micropropagation of Aloe vera (L.) Revista Brasileira de Plantas Medicinais 9:36-43.

Debnath, S.C. 2005. Strawberry sepal: Another explant for thidiazuron induced adventitious shoot regeneration. In vitro Cellular Developmental Biology Plant 41:671-676.

Faisal, M., N. Ahmad, and M.F. Anis. 2005. Shoot multiplication in Rauvolfia tetraphylla L. using thidiazuron. Plant Cell, Tissue and Organ Culture 80(2):87-190.

Hosseini, R., and M. Parsa. 2007. Micropropagation of Aloe vera L. grown in South Iran. Pakistan Journal of Biological Sciences 10:1134-1137.
Iram, S., and M. Anis. 2007. In vitro shoot multiplication and plantlet regeneration from nodal explants of Cassia angustifolia (Vahl.): a medicinal plant. Acta Physiologiae Plantarum 29:233-238.

Liao, Z., M. Chen, F. Tan, X. Sun, and K. Tang. 2004. Micropropagation of endangered Chinese aloe. Plant Cell, Tissue and Organ Culture 76:83-86.

Linchy, A.K., and B. Sasikumar. 2010. Enhanced adventitious shoot regeneration from aerial stem explants of ginger using TDZ and its histological studies. Turkish Journal of Botany 34:21-29.

Ni, Y., D. Turner, K.M. Yates, and I. Tizard. 2004. Isolation and characterization of structural components of Aloe vera L. leaf pulp. International Immunopharmacology 4:1745-1755.

Park, Y.I., and S.K. Lee. 2006. New perspectives on aloe. In Kim, Y.S. (ed.) Carbohydrates. Springer, New York, USA.

Qu, L., J. Polashock, and N. Vorsa. 2000. A high efficient in vitro cranberry regeneration system using leaf explants. Horticultural Science 35:948-952.

Silva, C.G., C. Debiasi, e R. Pescador. 2007. Enraizamiento in vitro e aclimatização de mudas micropropagadas de Aloe vera (L.) Revista Brasileira de Plantas Medicinais 9:29-35.

Tanabe, M.J., and K. Horiuchi. 2006. Aloe barbadensis Mill. ex vitro autotrophic culture. Journal of Hawaiian Pacific Agriculture 13:55-59.

Tawfik, A.A., and M.F. Mohamed. 2006. Shoot differentiation and plant regeneration from thidiazuron-induced callus of Salvia officinalis. Acta Horticulturae 723:309-314.

Velcheva, M., Z. Faltin, A. Vardi, Y. Eshdat, and A. Peral. 2005. Regeneration of Aloe arborescens via organogenesis from young inflorescences. Plant Cell, Tissue and Organ Culture 83:293-301.

Wenping, D., D. Shi, L. Xu, G. Yu, and W. Mili. 2004. A preliminary study on the induction and propagation of adventitious buds for Aloe vera L. Southeast China Journal of Agricultural Sciences 17:224-227.

Zuraida, A.R., A.H. Nurul Shahnadz, A. Harteeni, S. Roowi, C.M.Z. Che Radziah, and S. Sreeramanan. 2011. A novel approach for rapid micropropagation of maspine pineapple (Ananas comosus L.) shoots using liquid shake culture system. African Journal of Biotechnology 10:3859-3866. 